\title{
Outcomes and Prognostic Factors Following High-dose Re-irradiation for Recurrent Lung Cancer
}

Keisuke Tamari ( $\square$ tamari@radonc.med.osaka-u.ac.jp )

Osaka University Graduate School of Medicine https://orcid.org/0000-0002-2290-1905

Hiroshi Doi

Kinki Daigaku

Hiroya Shiomi

Osaka Daigaku Daigakuin Igakukei Kenkyuka Igakubu

Ryoongjin Oh

Miyakojima IGRT clinic

Kazuhiko Ogawa

Osaka Daigaku Daigakuin Igakukei Kenkyuka Igakubu

\section{Research}

Keywords: lung cancer, re-irradiation, late toxicities, histology, IMRT

Posted Date: February 25th, 2021

DOI: https://doi.org/10.21203/rs.3.rs-251694/v1

License: (c) (1) This work is licensed under a Creative Commons Attribution 4.0 International License. Read Full License 


\section{Abstract}

Background: Re-irradiation is one of the treatment options for recurrence after initial radiotherapy for locally advanced lung cancer. However, the safety and efficacy of high-dose re-irradiation for recurrent lung cancer has yet to be completely understood. This study investigated the outcomes of high-dose reirradiation for patients with recurrent lung cancer at our clinic.

Methods: Data were collected from 36 patients with lung cancer (median age, 68 years) who received high-dose re-irradiation using intensity-modulated radiotherapy for locoregional recurrence after initial radiotherapy in the locally advanced stage. Histology findings showed that 11 (30.6\%), 14 (38.9\%), and $11(30.6 \%)$ patients had adenocarcinoma, squamous cell carcinoma, and small cell carcinoma, respectively. The interval from initial radiotherapy to reirradiation was 23.4 months. Local control (LC), progression-free survival (PFS), and overall survival (OS) were evaluated. Univariate and multivariate analyses were performed to identify prognostic factors, while late toxicities $\geq$ grade3 were evaluated according to the CTCAE ver. 3.0.

Results: The median follow-up was 14.6 months. The 1 -year LC, PFS, and OS were $74.1 \%, 45.2 \%$, and $78.7 \%$, respectively. Multivariate analysis showed that histology was a significant prognostic factor for LC $(p=0.02)$, while histology $(p=0.04)$ and distant metastasis $(p=0.01)$ were significant prognostic factors for PFS. Grade 5 late toxicities occurred in 2 patients (5.6\%) who exhibited esophageal perforation and bronchial perforation. No other $\geq$ grade3 late toxicities occurred.

Conclusion: High-dose re-irradiation for recurrent locally advanced lung cancer was effective and feasible. Lung adenocarcinoma might therefore be a good indication for re-irradiation.

\section{Background}

Lung cancer remains the leading cause of cancer incidence and mortality, with 2.1 million new lung cancer cases and 1.8 million deaths worldwide.[1] Radiotherapy plays a significant role in the treatment of patients with non-small cell lung cancer (NSCLC) and small cell lung cancer (SCLC).[2, 3] Studies have shown that radiotherapy had a local control of $63 \%, 44 \%, 38 \%$, and $32 \%$ at $1,2,3$, and at 5 years in locally advanced NSCLC, respectively, and $61 \%$ at 2 years in limited-stage SCLC. $[4,5]$ This implies that in-field recurrence after radiotherapy for advanced lung cancer is not uncommon. Several treatment options, such as radiotherapy, surgery, immunotherapy, chemotherapy, and targeted therapy, have been considered for recurrent lung cancer.[6, 7] However, post-radiotherapy complications following re-irradiation for lung cancer recurring after radiotherapy have remained of great concern due to the increased cumulative dose to normal organs. Nonetheless, avoiding normal tissues with intensity-modulated radiotherapy (IMRT) or stereotactic body radiotherapy (SBRT) during re-irradiation may keep the cumulative dose to normal tissues as low as possible and increase safety. Given the small number of reports available on high-dose re-irradiation for in-field recurrence of advanced lung cancer after initial radiotherapy,[8] its efficacy and safety, as well as those who exhibit good prognosis with re-irradiation, have remained uncertain.

The current study analyzed patients who underwent re-irradiation for recurrent lung cancer after radiotherapy at our clinic and determined the efficacy of treatment, adverse events, and characteristics of patients with good prognosis after re-irradiation.

\section{Methods}

\section{Patient characteristics}

Data were collected from 36 patients with lung cancer (median age, 68 years; range, 45-88 years) who received definitive re-irradiation using IMRT for local recurrence after (chemo-)radiotherapy in the locally advanced stage. The patient characteristics are summarized in Table 1. Among the included patients, $29(80.6 \%)$ and 7 (19.4\%) were male and female, respectively. Performance status (PS) according to Eastern Cooperative Oncology Group (ECOG) was 0-1 and $2-3$ in 31 (86.1\%) and 5 (5.6\%) patients, respectively. Histology findings showed that $11(30.6 \%), 14(38.9 \%)$, and 11 (30.6\%) patients had adenocarcinoma, squamous cell carcinoma, and small cell carcinoma, respectively. Among the analyzed patients, 22 (61.1\%), 13 (36.1\%), and 1 (2.8\%) had primary site, lymph node, and both primary and lymph node recurrence, respectively, while $23(63.9 \%)$ and 7 (19.4\%) patients had recurrent tumors that came in contact with the trachea/bronchus and esophagus, respectively. The duration from initial radiotherapy to re-irradiation was 23.4 (range, 8.5-102.6) months. The median initial radiation dose, re-irradiation dose, and total dose (BED10) was 72 Gy (range, 48.0-84.0), 86.8 Gy (range, 56.0-119.6), and 154.3 Gy (range, 107.8-191.6), respectively, while the median follow-up was 14.6 months (range, 0.4-88.6). 
Table 1

Patient characteristics

\begin{tabular}{|c|c|c|c|}
\hline \multicolumn{4}{|l|}{ Characteristics } \\
\hline Age & Median (range) & 68 & $(45-88)$ \\
\hline \multirow[t]{2}{*}{ Sex } & Male & 29 & $(80.6 \%)$ \\
\hline & Female & 7 & $(19.4 \%)$ \\
\hline \multirow[t]{2}{*}{ PS } & 0,1 & 31 & $(86.1 \%)$ \\
\hline & $2-4$ & 5 & $(5.6 \%)$ \\
\hline \multirow[t]{3}{*}{ Histology } & $A C$ & 11 & $(30.6 \%)$ \\
\hline & SCC & 14 & $(38.9 \%)$ \\
\hline & SCLC & 11 & $(30.6 \%)$ \\
\hline \multirow[t]{3}{*}{ Recurrent sites } & Primary site & 22 & $(61.1 \%)$ \\
\hline & LNs & 13 & $(36.1 \%)$ \\
\hline & Both & 1 & $(2.8 \%)$ \\
\hline \multirow[t]{2}{*}{ Organs adjacent to the recurrent tumor } & Trachea/bronchus & 23 & $(63.9 \%)$ \\
\hline & Esophagus & 7 & $(19.4 \%)$ \\
\hline \multirow[t]{2}{*}{ DM } & Positive & 5 & $(13.9 \%)$ \\
\hline & Negative & 31 & $(86.1 \%)$ \\
\hline Treatment interval (months) & Median (range) & 23.4 & $(8.5-102.6)$ \\
\hline Dose of initial RT (BED10) & Median (range) & 72.0 & $(48.0-84.0)$ \\
\hline Dose of re-RT (BED10) & Median (range) & 86.8 & $(56.0-119.6)$ \\
\hline Cumulative dose (BED10) & Median (range) & 154.3 & $(107.8-191.6)$ \\
\hline PTV (cc) & Median (range) & 73.6 & $(8.8-460.6)$ \\
\hline
\end{tabular}

\section{Treatment}

Computed tomography (CT) and magnetic resonance imaging for treatment planning were obtained in the supine position using a BrightSpeed ${ }^{\text {TM }}$ CT scanner (GE Healthcare, Chicago, IL) and SIGNA EXCITE HDx 1.5T ${ }^{\mathrm{Tm}}$ (GE Healthcare, Chicago, IL). Clinical target volume (CTV) was considered equal to gross tumor volume (GTV), while the planning target volume (PTV) was calculated by adding a margin of approximately 5 mm to each CTV. Plans were generated using BrainSCAN (ver. 5.31) RT Treatment Planning Software (Brainlab AG, Munich, Germany) with the pencil beam algorithm before November 2010 and thereafter using iPlan RT Dose (ver. 4.1.2) software (Brainlab AG) with the Monte Carlo algorithm. All patients underwent IMRT using a 6-MV linear accelerator (Novalis, Brainlab AG). Daily image guidance was performed, while treatments were performed on consecutive days.

\section{Clinical outcome evaluation}

In principle, patients were followed-up after 4 weeks and then every 3 months thereafter, with CT being performed at each visit. The latest visit or date of contact was used for right-censoring patients who were alive at the time of analysis. Tumor responses after re-irradiation were evaluated using Response Evaluation Criteria in Solid Tumors ver1.1. ${ }^{10}$ Local control (LC) was defined as recurrence at the re-irradiated site. Progression-free survival (PFS) was as the duration from re-irradiation to disease progression or death from any cause. Overall survival (OS) was defined as the duration from re-irradiation to death from any cause. Late toxicities $\geq$ grade3 were evaluated according to the Common Terminology Criteria for Adverse Events ver. 3.0.

\section{Statistical analysis}

Data analysis was performed using JMP pro 14 (SAS Institute Inc., Cary, NC). LC, PFS, and OS rates were calculated using the Kaplan-Meier method. Prognostic factors were identified through univariate analysis using the log-rank test and multivariate analysis using the COX proportional hazards model. Statistical tests were based on a two-sided significance level, with $p$ values of $<0.05$ indicating statistical significance.

\section{Results}

\section{LC, progression-free survival, and overall survival}


The 1-year, 2-year, and median LC was $74.3 \%, 42.1 \%$, and 15.7 months, respectively (Fig. 1A). Multivariate analysis identified histology as a significant prognostic factor for LC ( $(\mathrm{p}=0.02)$. The 1 -year LC for adenocarcinoma, squamous cell carcinoma, and small cell carcinoma was $100 \%, 58.3 \%$, and $75.0 \%$, respectively (Fig. 1B). The 1-year, 2-year, and median PFS was $45.2 \%, 17.0 \%$, and 10.4 months, respectively (Fig. $2 \mathrm{~A}$ ). Multivariate analysis identified histology $(p=0.04)$ and distant metastasis $(p=0.01)$ as significant prognostic factors for PFS. The 1-year PFS for adenocarcinoma, squamous cell carcinoma, and small cell carcinoma was $63.6 \%, 58.3 \%$, and $10.4 \%$, respectively (Fig. 2B), while distant metastasis-positive and -negative disease had a 1year PFS of $0 \%$ and $53.1 \%$, respectively. The 1-year, 2-year, and median OS was $78.7 \%, 54.4 \%$, and 26.7 months, respectively (Fig. 3). Univariate analysis identified no significant prognostic factor for OS. Details regarding statistical analysis are presented in Table 2.

Table 2

Univariate and multivariate analyses for the factors associated with LC, PFS, and OS

\begin{tabular}{|c|c|c|c|c|c|c|c|c|c|c|c|}
\hline & & & LC & & & PFS & & & os & & \\
\hline \multicolumn{2}{|l|}{ Variables } & $n$ & $\begin{array}{l}\text { 1-year LC } \\
\text { (months) }\end{array}$ & $\begin{array}{l}\text { Univariate } \\
\mathrm{p} \text { value }\end{array}$ & $\begin{array}{l}\text { Multivariate } \\
\text { p value }\end{array}$ & $\begin{array}{l}\text { 1-year } \\
\text { PFS } \\
\text { (months) }\end{array}$ & $\begin{array}{l}\text { Univariate } \\
\mathrm{p} \text { value }\end{array}$ & $\begin{array}{l}\text { Multivariate } \\
\mathrm{p} \text { value }\end{array}$ & $\begin{array}{l}\text { 1-year } \\
\text { OS } \\
\text { (months) }\end{array}$ & $\begin{array}{l}\text { Univariate } \\
\mathrm{p} \text { value }\end{array}$ & $\begin{array}{l}\text { Multivariate } \\
\mathrm{p} \text { value }\end{array}$ \\
\hline \multirow[t]{2}{*}{ Age } & $\geq 68$ & 17 & $67.5 \%$ & 0.26 & - & $41.9 \%$ & 0.32 & - & $76.9 \%$ & 0.76 & - \\
\hline & $<68$ & 19 & $82.5 \%$ & & & $48.1 \%$ & & & $79.4 \%$ & & \\
\hline \multirow[t]{2}{*}{ Gender } & Male & 29 & $72.9 \%$ & 0.19 & - & $45.0 \%$ & 0.46 & - & $83.5 \%$ & 1.00 & - \\
\hline & Female & 7 & $83.3 \%$ & & & $50.0 \%$ & & & $50.0 \%$ & & \\
\hline \multirow[t]{2}{*}{ PS } & 0,1 & 33 & $72.8 \%$ & 0.25 & - & $44.7 \%$ & 0.42 & - & $81.2 \%$ & 0.93 & - \\
\hline & $\geq 2$ & 3 & $100 \%$ & & & $66.7 \%$ & & & $50.0 \%$ & & \\
\hline \multirow[t]{3}{*}{ histology } & $A C$ & 11 & $100 \%$ & $<0.01$ & 0.02 & $63.6 \%$ & $<0.01$ & 0.04 & $67.5 \%$ & 0.09 & - \\
\hline & SCC & 14 & $58.3 \%$ & & & $58.3 \%$ & & & $100 \%$ & & \\
\hline & SCLC & 11 & $75.0 \%$ & & & $10.4 \%$ & & & $59.3 \%$ & & \\
\hline \multirow[t]{2}{*}{ DM } & Positive & 5 & $100 \%$ & 0.17 & - & $0 \%$ & $<0.01$ & 0.01 & $66.7 \%$ & 0.08 & - \\
\hline & negative & 31 & $72.2 \%$ & & & $53.1 \%$ & & & $79.8 \%$ & & \\
\hline \multirow{2}{*}{$\begin{array}{l}\text { Interval } \\
\text { (months) }\end{array}$} & $\geq 24$ & 19 & $86.7 \%$ & 0.93 & - & $57.0 \%$ & 0.81 & - & $72.1 \%$ & 0.86 & - \\
\hline & $<24$ & 17 & $63.5 \%$ & & & $35.4 \%$ & & & $85.9 \%$ & & \\
\hline \multirow{2}{*}{$\begin{array}{l}\text { Re-RT } \\
\text { dose } \\
\text { (BED10) }\end{array}$} & $\geq 85$ & 18 & $79.3 \%$ & 0.32 & - & $57.6 \%$ & 0.03 & 0.24 & $80.7 \%$ & 0.60 & - \\
\hline & $<85$ & 18 & $68.4 \%$ & & & $32.4 \%$ & & & $76.7 \%$ & & \\
\hline \multirow{2}{*}{$\begin{array}{l}\text { PTV } \\
\text { volume } \\
\text { (cc) }\end{array}$} & $\geq 74$ & 18 & $92.3 \%$ & $<0.01$ & 0.06 & $39.8 \%$ & 0.19 & - & $75.0 \%$ & 0.87 & - \\
\hline & $<74$ & 18 & $55.6 \%$ & & & $50.4 \%$ & & & $84.4 \%$ & & \\
\hline
\end{tabular}

Abbreviations: SCC, squamous cell carcinoma; AC, adenocarcinoma; SCLC, small cell lung cancer; NSCLC, non-small cell carcinoma; NOS, not otherwise specified; LC, local control; PFS, progression-free survival; OS, overall survival; RT, radiotherapy; NR, not reported; BED, biological effective dose; conv, conventional radiotherapy; PTV, planning target volume; $G$, grade; b/w, between; DM, distant metastases

\section{Toxicities}

Grade 5 late toxicities occurred in 2 patients (5.6\%), with no other $\geq$ grade3 late toxicities having occurred. One patient, a 70-year-old woman, underwent reirradiation with 66 Gy in 30 fractions for mediastinal lymph node recurrence that appeared 59.4 months after chemoradiation with 60 Gy in 30 fractions for locally advanced lung adenocarcinoma. She developed esophageal perforation and died 11.3 months after re-irradiation. CT before re-irradiation showed lymph node metastasis with suspected esophageal invasion. The other patient, a 59-year-old male with locally advanced squamous cell carcinoma of the primary trachea, developed local recurrence 20.7 months after initial chemoradiation with $60 \mathrm{~Gy}$ in 30 fractions and was re-irradiated with 70 Gy in 28 fractions. The patient developed tracheal perforation 8.2 months after irradiation and died.

\section{Discussion}

The current study retrospectively analyzed patients who received high-dose re-irradiation for recurrent lung cancer after initial radiotherapy. Although several studies have been available on high-dose re-irradiation after radiotherapy for locally advanced lung cancer, albeit in a relatively small number of patients, the efficacy, safety, and prognostic factors have varied.[9-14] Table 3 briefly summarizes the previous studies, including our results. 
Table 3

Summary of published studies on treatment outcomes of re-irradiation for recurrent lung cancer.

\begin{tabular}{|c|c|c|c|c|c|c|c|c|c|c|}
\hline Study & $\mathbf{n}$ & Histology & $\begin{array}{l}\text { Median } \\
\text { follow-up } \\
\text { (months) }\end{array}$ & $\begin{array}{l}\text { Median } \\
\text { interval } \\
\text { (months) }\end{array}$ & $\begin{array}{l}\text { Median } \\
\text { initial } \\
\text { dose }\end{array}$ & $\begin{array}{l}\text { Median } \\
\text { re- } \\
\text { irradiation } \\
\text { dose }\end{array}$ & LC & OS & $\begin{array}{l}\text { Severe late } \\
\text { toxicities } \\
\text { ( } \geq \mathrm{G} 3 \text { ) }\end{array}$ & Prognostic factors \\
\hline \multirow{3}{*}{$\begin{array}{l}\text { Wu et al } \\
\text { [9] }\end{array}$} & \multirow[t]{3}{*}{23} & SCC: 9 & \multirow[t]{3}{*}{15} & \multirow[t]{3}{*}{13} & \multirow{3}{*}{$\begin{array}{l}66 \mathrm{~Gy} \\
\text { conv }\end{array}$} & \multirow{3}{*}{$\begin{array}{l}51 \mathrm{~Gy} \\
\text { conv }\end{array}$} & 1y: $51 \%$ & 1y: $59 \%$ & \multirow{3}{*}{$\begin{array}{l}\text { G3 pulmonary } \\
\text { fibrosis }(n=2)\end{array}$} & \multirow[t]{3}{*}{ NR } \\
\hline & & AC: 7 & & & & & $2 y: 42 \%$ & $2 y: 21 \%$ & & \\
\hline & & SCLC: 7 & & & & & & & & \\
\hline \multirow{5}{*}{$\begin{array}{l}\text { Kelly et al } \\
\text { [10] }\end{array}$} & \multirow[t]{5}{*}{36} & & \multirow[t]{5}{*}{15} & \multirow[t]{5}{*}{22} & \multirow[t]{5}{*}{$\begin{array}{l}61.5 \\
\text { Gy }\end{array}$} & \multirow[t]{5}{*}{$\begin{array}{l}50 \mathrm{~Gy} / 4 \\
\mathrm{Fx}\end{array}$} & \multirow[t]{5}{*}{ NR } & 1y: $59 \%$ & \multirow{3}{*}{$\begin{array}{l}\text { G3 cough }(\mathrm{n}= \\
1) \\
\text { G3 } \\
\text { pneumonitis } \\
(\mathrm{n}=7)\end{array}$} & \multirow{5}{*}{$\begin{array}{l}\text { Isolated recurrence } \\
\text { outside the previous } \\
\text { treatment field for } \\
\text { PFS. }\end{array}$} \\
\hline & & AC: 14 & & & & & & $2 \mathrm{y}: 43 \%$ & & \\
\hline & & $\begin{array}{l}\text { NSCLC, } \\
\text { NOS: } 8\end{array}$ & & & & & & & & \\
\hline & & Other: 2 & & & & & & & $\begin{array}{l}\text { G3 } \\
\text { esophagitis ( } \mathrm{n} \\
=3 \text { ) }\end{array}$ & \\
\hline & & & & & & & & & G3 skin $(n=2)$ & \\
\hline \multirow[t]{3}{*}{$\begin{array}{l}\text { McAvoy } \\
\text { et al [11] }\end{array}$} & \multirow[t]{3}{*}{33} & SCC: 14 & \multirow[t]{3}{*}{11} & \multirow[t]{3}{*}{36} & \multirow[t]{3}{*}{$66 \mathrm{~Gy}$} & \multirow{3}{*}{$\begin{array}{l}66 \mathrm{~Gy} \\
\text { (RBE) } \\
\text { proton } \\
\text { beam }\end{array}$} & \multirow[t]{3}{*}{ 1y: $54 \%$} & \multirow[t]{3}{*}{ 1y: $47 \%$} & \multirow{3}{*}{$\begin{array}{l}\text { G4 } \\
\text { esophagitis ( } \mathrm{n} \\
=1 \text { ) } \\
\text { G4 tracheal } \\
\text { necrosis ( } \mathrm{n}= \\
2 \text { ) }\end{array}$} & \multirow[t]{3}{*}{ NR } \\
\hline & & AC: 15 & & & & & & & & \\
\hline & & NSCLC: 4 & & & & & & & & \\
\hline \multirow[t]{2}{*}{$\begin{array}{l}\text { Griffioen } \\
\text { et al [12] }\end{array}$} & \multirow[t]{2}{*}{24} & $\begin{array}{l}\text { NSCLC: } \\
22\end{array}$ & \multirow[t]{2}{*}{19.3} & 51 & $\begin{array}{l}59.8 \\
\text { Gy }\end{array}$ & 60 Gy & $\begin{array}{l}\text { Median: } 6.7 \\
\text { mo }\end{array}$ & $1 y: 51 \%$ & $\begin{array}{l}\text { G5 Bleeding } \\
(n=3)\end{array}$ & PTV size for OS \\
\hline & & SCLC: 2 & & & & & & & & \\
\hline Sumita et & 21 & SCC: 6 & 22.1 & 26.8 & NSCLC: & NSCLC: & 1y: $57 \%$ & 1y: 76\% & G3 & Re-RT dose for LC \\
\hline & & AC: 5 & & & & & $2 y: 34 \%$ & $2 y: 64 \%$ & $(n=1)$ & PTV size for OS \\
\hline & & SCLC: 7 & & & 43.1Gy & $50 \mathrm{~Gy}$ & & & & \\
\hline & & other: 3 & & & & & & & & \\
\hline $\begin{array}{l}\text { Schlampp } \\
\text { et al [14] }\end{array}$ & 62 & SCC: 32 & 8.2 & 14 & 60 Gy & 38.5 Gy & $\begin{array}{l}\text { Median: } 6.5 \\
\text { mo }\end{array}$ & $\begin{array}{l}\text { Median: } \\
9 \text { mo }\end{array}$ & $\begin{array}{l}\text { G5 } \\
\text { pneumonitis }\end{array}$ & $\begin{array}{l}\text { Number of involved } \\
\text { LNs, dose of re-RT }\end{array}$ \\
\hline & & AC: 16 & & & & & & & $(n=1)$ & $\begin{array}{l}\text { and interval b/w RT } \\
\text { and re-RT for OS }\end{array}$ \\
\hline & & SCLC: 10 & & & & & & & G4 & \\
\hline & & Others: 4 & & & & & & & fistula $(n=1)$ & \\
\hline & & & & & & & & & $\begin{array}{l}\text { G3 } \\
\text { esophageal } \\
\text { stenosis }(n= \\
1)\end{array}$ & \\
\hline & & & & & & & & & $\begin{array}{l}\text { G3 } \\
\text { pneumothorax } \\
(n=1)\end{array}$ & \\
\hline & & & & & & & & & $\begin{array}{l}\text { G3 } \\
\text { pneumonitis } \\
(n=2)\end{array}$ & \\
\hline $\begin{array}{l}\text { This } \\
\text { study }\end{array}$ & 36 & SCC: 14 & 16 & 23 & $\begin{array}{l}\text { NSCLC: } \\
60 \mathrm{~Gy}\end{array}$ & $\begin{array}{l}86.8 \mathrm{~Gy} \\
(\mathrm{BED}\end{array}$ & 1y: 74\% & 1y: 79\% & G5 & $\begin{array}{l}\text { Histology for LC and } \\
\text { PFS }\end{array}$ \\
\hline & & AC: 11 & & & SCLC: & & $2 y: 42 \%$ & $2 y: 54 \%$ & $\begin{array}{l}\text { perforation ( } \mathrm{n} \\
=1 \text { ) }\end{array}$ & \\
\hline & & SCLC: 11 & & & $\begin{array}{l}45 G y \\
\text { conv }\end{array}$ & & $\begin{array}{l}\text { Median:15.7 } \\
\text { mo }\end{array}$ & $\begin{array}{l}\text { Median: } \\
26.7 \\
\text { mo }\end{array}$ & $\begin{array}{l}\text { G5 tracheal } \\
\text { perforation ( } \mathrm{n} \\
=1 \text { ) }\end{array}$ & \\
\hline
\end{tabular}


Available studies on the outcomes of re-irradiation after curative irradiation for locally advanced lung cancer have shown a 1-year LC of 51-57\% with a median duration of 6.5-6.7 months and 1-year OS of 47-76\% with a median duration of 9 months. [9-14] The current study showed a 1-year LC rate of $74 \%$ with a median duration of 15.7 months and a 1-year OS of $79 \%$ with a median duration of 26.7 months. We believe that our results were better than those reported previously, which may perhaps be due to the higher re-irradiation dose used herein. The aforementioned studies also identified various prognostic factors for high-dose re-irradiation after radiotherapy for advanced lung cancer. Accordingly, Sumita et al. reported that a re-irradiation dose of 60 Gy or more was a favorable prognostic factor for LC (median LC rate 18.2 vs. 6.8 months).[13] The current study, on the other hand, identified histology as a prognostic factor for LC and PFS, a novel finding that may help determine recurrence after radiotherapy. Moreover, given that our median re-irradiation dose was higher than that used previously, the difference in LC rate according to histological type may become apparent during high-dose re-irradiation. Although data are not shown, our analysis revealed that systemic therapy after re-irradiation did not contribute to LC, PFS, and OS. In an analysis of stereotactic radiotherapy for patients with NSCLC, Shiue et al. reported that adenocarcinoma, small GTV, and high prescription dose were favorable prognostic factors and suggested avoiding low prescription doses for SCC.[15] In the case of lung cancer re-irradiation, higher doses for squamous cell carcinoma may improve LC rates, despite the potential risk for adverse events when recurrence develops close to a risk organ.

Given that serious adverse events may occur during lung cancer re-irradiation, caution is required. The incidence of G3 or higher adverse events has been reported to vary from $4.8-36.1 \%,[9-14]$ which may be attributed to the prescribed dose and radiotherapy technique used. Given that the incidence of adverse events above G3 was only 5.5\% in the current study, we believe that the treatment was relatively safer compared to previous reports. The current study observed two G5 cases, one involving esophageal perforation and the other involving tracheal perforation. In the case of high-dose re-irradiation near the trachea and esophagus or in cases of direct invasion to trachea, bronchus, and esophagus, careful explanation should be given to the patients prior to obtaining consent given the risk for serious adverse events. Incidentally, we are in the process of analyzing the relationship between late toxicities after reirradiation and cumulative dose to risk organs.

Some limitations of the current study are worth noting. First, this was a retrospective study that included a limited number of patients. Second, posttreatment after re-irradiation varied, while the dose and number of fractions for re-irradiation had not been standardized. Moreover, it remains unclear whether the similar results would obtained in the case of recurrence after the PACIFIC regimen, especially for NSCLC, given that this was before the PACIFIC regimen was introduced. Considering that local recurrence is not uncommon even after treatment of NSCLC with PACIFIC regimens,[16] salvage therapy with re-irradiation might be a good option. Given the risks involved with surgical resection of the chest after radical irradiation,[17] we believe that the possibility of high-dose re-irradiation as a salvage treatment should be explored.

\section{Conclusion}

Our results indicated that high-dose re-irradiation after radiotherapy for advanced lung cancer is a relatively safe and effective treatment and may be considered a treatment option for recurrent lung cancer. Moreover, patients with lung adenocarcinoma had high LC rates, which may be useful in determining indications. Nonetheless, further validation of high-dose re-irradiation for recurrence after lung cancer radiotherapy is needed through prospective studies.

\section{Declarations}

\section{Ethics approval and consent to participate}

The institutional review board of Miyakojima IGRT Clinic approved our study protocol (study number: M6), while all participants provided informed consent prior to treatment.

\section{Consent for publication}

Not applicable.

\section{Availability of data and materials}

The datasets used and/or analysed during the current study are available from the corresponding author on reasonable request.

\section{Competing interests}

None.

\section{Funding}

This research did not receive any specific grant from funding agencies in the public, commercial, or not-for-profit sectors.

\section{Authors' contributions}

KT obtained IRB approval and built the patient database, wrote the manuscript. HD and HS conducted statistical analysis. RO and KO designed the study and conducted interpretation of data. All authors read and approved the final manuscript.

\section{Acknowledgements}


The authors would like to thank Enago for English language review.

\section{References}

1. Siegel RL, Miller KD, Jemal A. Cancer statistics, 2019. CA Cancer J Clin. 2019;69:7-34.

2. van Meerbeeck JP, Fennell DA, De Ruysscher DK. Small-cell lung cancer. Lancet [Internet]. 2011;378:1741-55. Available from: https://linkinghub.elsevier.com/retrieve/pii/S0140673611601657

3. Vansteenkiste J, De Ruysscher D, Eberhardt WEE, Lim E, Senan S, Felip E, et al. Early and locally advanced non-small-cell lung cancer (NSCLC): ESMO Clinical Practice Guidelines for diagnosis, treatment and follow-up. Ann Oncol Off J Eur Soc Med Oncol [Internet]. 2013;24 Suppl 6:vi89-98. Available from: http://www.ncbi.nlm.nih.gov/pubmed/23860613

4. Bütof R, Gumina C, Valentini C, Sommerer A, Appold S, Zips D, et al. Sites of recurrent disease and prognostic factors in SCLC patients treated with radiochemotherapy. Clin Transl Radiat Oncol. 2017;7:36-42.

5. MacHtay M, Paulus R, Moughan J, Komaki R, Bradley J, Choy H, et al. Defining local-regional control and its importance in locally advanced non-small cell lung carcinoma. J Thorac Oncol. 2012;7:716-22.

6. Sugimura H, Nichols FC, Yang P, Allen MS, Cassivi SD, Deschamps C, et al. Survival After Recurrent Nonsmall-Cell Lung Cancer After Complete Pulmonary Resection. Ann Thorac Surg. 2007;83:409-18.

7. Yuan M, Huang LL, Chen JH, Wu J, Xu Q. The emerging treatment landscape of targeted therapy in non-small-cell lung cancer. Signal Transduct Target Ther [Internet]. Springer US; 2019;4. Available from: http://dx.doi.org/10.1038/s41392-019-0099-9

8. De Ruysscher D, Faivre-Finn C, Le Pechoux C, Peeters S, Belderbos J. High-dose re-irradiation following radical radiotherapy for non-small-cell lung cancer. Lancet Oncol. 2014;15:e620-4.

9. Wu KL, Jiang GL, Qian H, Wang LJ, Yang HJ, Fu XL, et al. Three-dimensional conformal radiotherapy for locoregionally recurrent lung carcinoma after external beam irradiation: A prospective phase I-II clinical trial. Int J Radiat Oncol Biol Phys. 2003;57:1345-50.

10. Kelly P, Balter PA, Rebueno N, Sharp HJ, Liao Z, Komaki R, et al. Stereotactic body radiation therapy for patients with lung cancer previously treated with thoracic radiation. Int J Radiat Oncol Biol Phys. 2010;78:1387-93.

11. McAvoy SA, Ciura KT, Rineer JM, Allen PK, Liao Z, Chang JY, et al. Feasibility of proton beam therapy for reirradiation of locoregionally recurrent nonsmall cell lung cancer. Radiother Oncol [Internet]. Elsevier Ireland Ltd; 2013;109:38-44. Available from: http://dx.doi.org/10.1016/j.radonc.2013.08.014

12. Griffioen GHMJ, Dahele M, De Haan PF, Van de Ven PM, Slotman BJ, Senan S. High-dose, conventionally fractionated thoracic reirradiation for lung tumors. Lung Cancer [Internet]. Elsevier Ireland Ltd; 2014;83:356-62. Available from: http://dx.doi.org/10.1016/j.lungcan.2013.12.006

13. Sumita K, Harada H, Asakura H, Ogawa H, Onoe T, Murayama S, et al. Re-irradiation for locoregionally recurrent tumors of the thorax: A singleinstitution, retrospective study. Radiat Oncol [Internet]. Radiation Oncology; 2016;11:5-12. Available from: http://dx.doi.org/10.1186/s13014-016-0673-

z

14. Schlampp I, Rieber J, Adeberg S, Bozorgmehr F, Heußel CP, Steins M, et al. Re-irradiation in locally recurrent lung cancer patients. Strahlentherapie und Onkol. 2019;195:725-33.

15. Shiue K, Cerra-Franco A, Shapiro R, Estabrook N, Mannina EM, Deig CR, et al. Histology, Tumor Volume, and Radiation Dose Predict Outcomes in NSCLC Patients After Stereotactic Ablative Radiotherapy. J Thorac Oncol [Internet]. Elsevier Inc; 2018;13:1549-59. Available from: https://doi.org/10.1016/j.jtho.2018.06.007

16. Raben D, Rimner A, Senan S, Broadhurst H, Pellas T, Dennis PA, et al. Patterns of Disease Progression with Durvalumab in Stage III Non-small Cell Lung Cancer (PACIFIC). Int J Radiat Oncol. Elsevier Inc; 2019;105:683.

17. Dickhoff C, Dahele M, Hashemi SM, Senan S, Smit EF, Hartemink KJ, et al. Surgical Treatment of Complications After High-Dose Chemoradiotherapy for Lung Cancer. Ann Thorac Surg. The Society of Thoracic Surgeons; 2017;104:436-42.

\section{Figures}


A

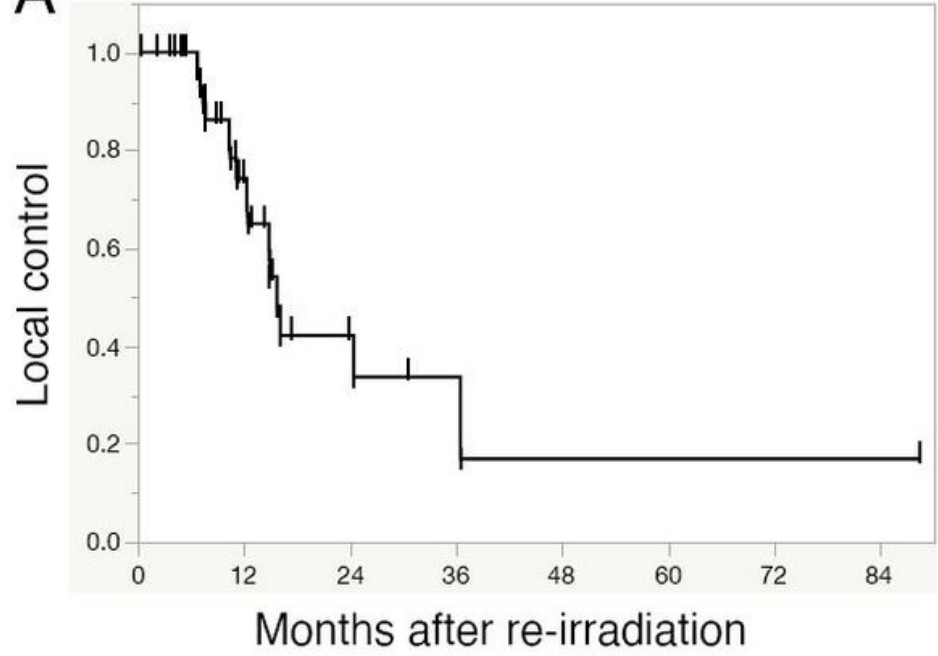

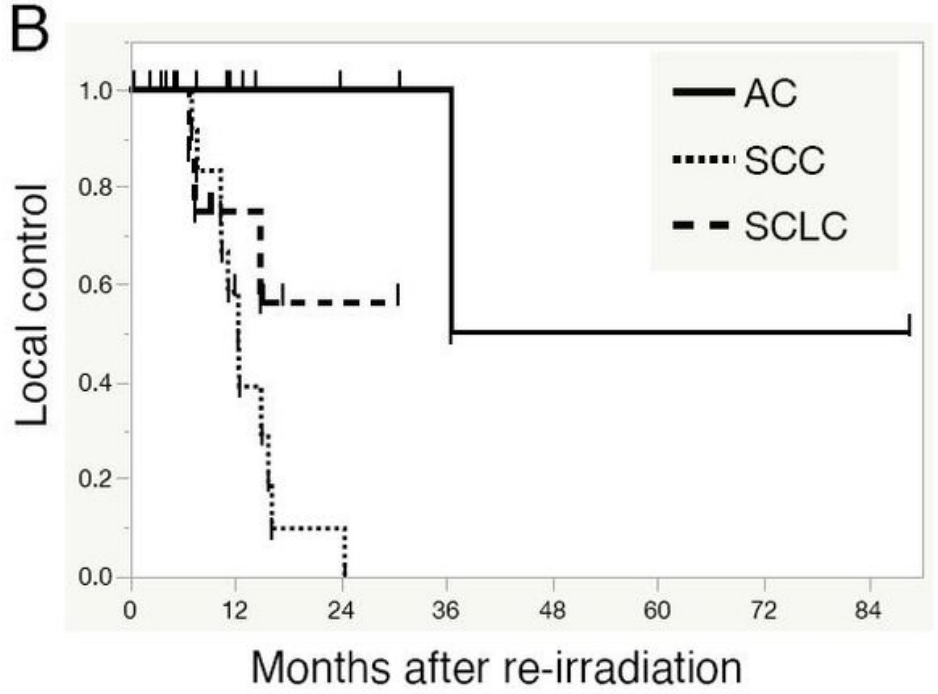

Figure 1

LC, progression-free survival and overall survival A. Local control (LC) in all patients. The 1-year, 2-year, and median LC was $74.3 \%, 42.1 \%$ and 15.7 months, respectively. B. LC stratified according to histology. The 1-year LC rates were 100\% in AC, $58.3 \%$ in SCC, and $75.0 \%$ in SCLC.

A

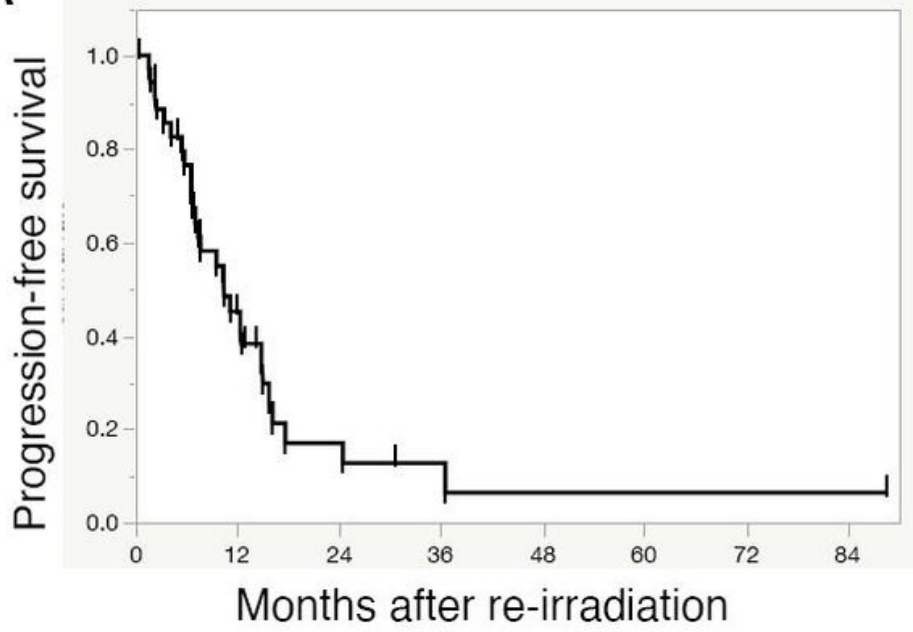

$\mathrm{B}$

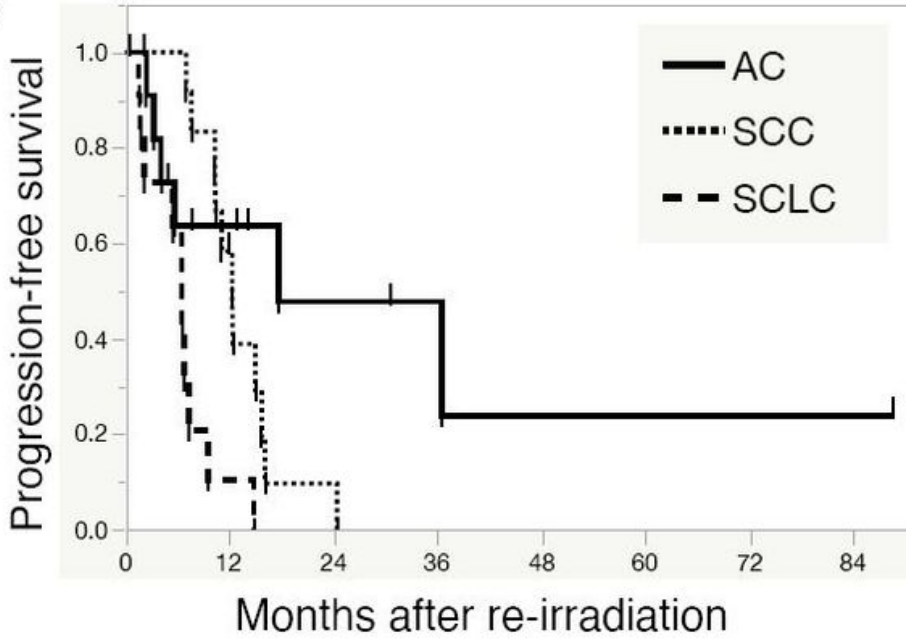

Figure 2

Progression-free survival A. The 1-year, 2-year, and median progression-free survival (PFS) was 45.2\%, $17.0 \%$, and 10.4 months, respectively. B. Local control (LC) stratified according to histology. The 1-year PFS rates were $63.6 \%$ in AC, $58.3 \%$ in SCC, and $10.4 \%$ in SCLC 


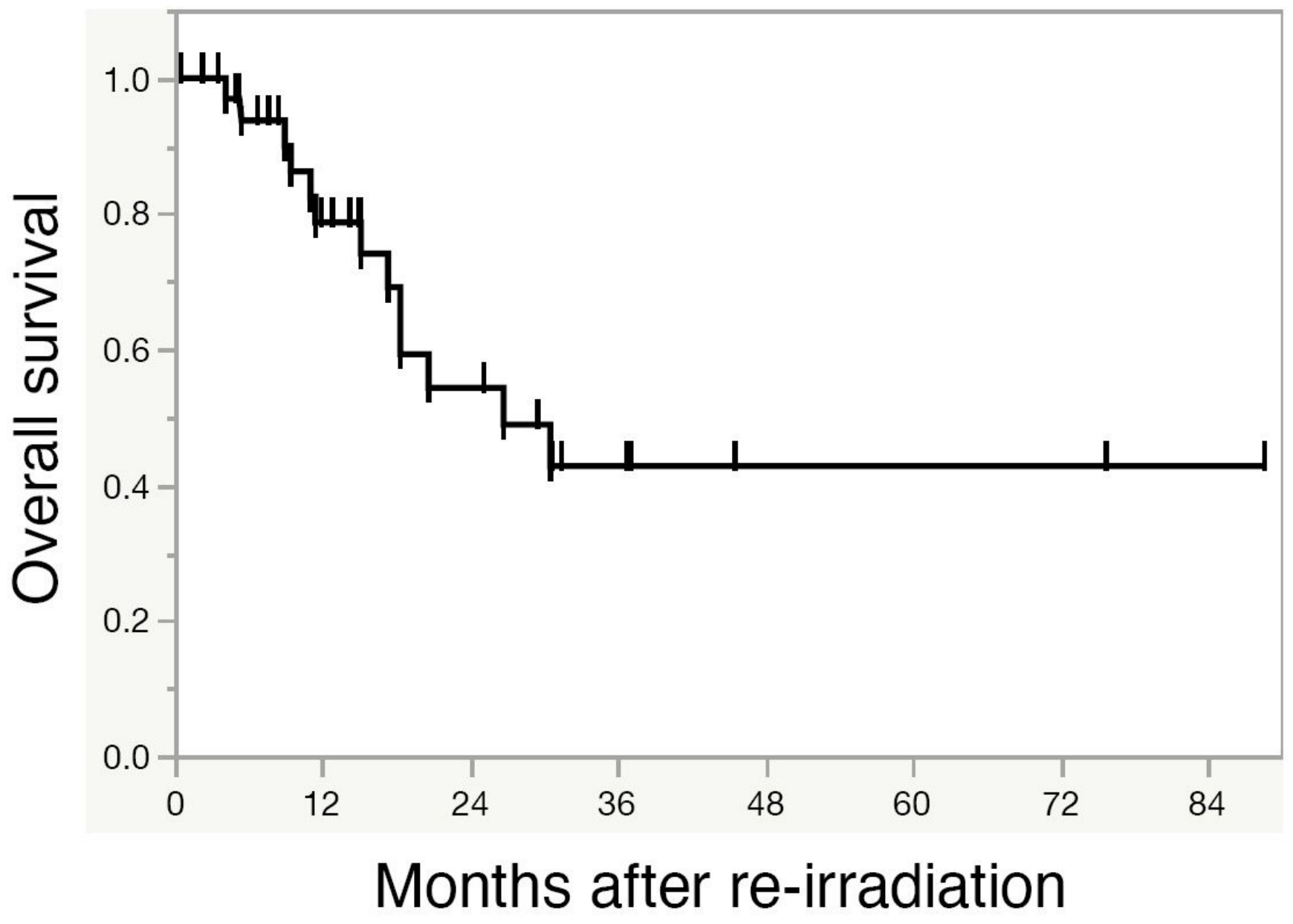

Figure 3

Overall survival Overall survival (OS) of all patients. The 1-year, 2-year, and median OS was $78.7 \%, 54.4 \%$ and 26.7 months, respectively. 